\title{
来館目的と利用行動からみた複合公立図書館の利用実態に関する研究 \\ St, Tg 館における施設利用者の来館目的と利用空間のつながりについて \\ RESEARCH ON THE ACTUAL USE OF THE COMPLEX PUBLIC LIBRARY FROM THE PERSPECTIVES OF VISITING PURPOSE AND USAGE BEHAVIOR
}

Connection between users' visiting purpose and space usage at St, Tg libraries

志 波 文 彦*1, 福 本 七 海*2, 二田水 宏次*3

\section{Fumihiko SHIWA, Nanami FUKUMOTO and Koji NITAMIZU}

\begin{abstract}
This research clarifies the following issues to obtain useful knowledge for future public library planning by capturing the behavior of the complex public library based on the user's purpose of visit. First, the functional structure and management policy of the complex public library in recent years were examined. Second, the connection between users' purpose of visit and the space used at St and Tg libraries were clarified. Finally, the users' purpose of visit, patterns and development of "by-the-way use," and expansion of space used under "stop by use" were evaluated to determine the usage structure of the stay-oriented library.
\end{abstract}

Keywords : Library, Designated manager, Facility complex, Management policy, Purpose of visit, Usage behavior 図書館, 指定管理者, 複合化, 運営方針, 来館目的, 利用行動

\section{1. はじめに}

2003 年の地方自治法改正による指定管理者制度の創設以降、公共 施設の管理を民間団体へ委託することが可能となり、従来なかった 様々な空間や機能、サービスの提供や他施設との積極的な複合化を 行う公立図書館が見られるようになった。制度創設以降、指定管理 者制度を導入する公立図書館は増え続け、2015 年の調查では全体の 約 $15.6 \%$ にたる 516 館で導入されており文1)、近年では新築図書 館の半数以上が複合図書館となっている注 ${ }^{1)}$ 。中には図書館を核とし、 地域の中心的な賑わいの場とするために積極的に他施設との複合化 が行われる事例も見られるようになるなど施設利用者の来館目的や 空間の使われ方も多様化している。特に複合公立図書館では、しば しば同一施設内における図書館と他施設の相互利用が行われるが、 多様な性格の施設が複合化されていることによって当初来館の目的 とした施設以外の利用（以下、ついで利用）が行われたり、駅やコ ンビニ等の交通・利便施設等と近接した立地条件にあることで特定 の来館目的をもたない利用 (以下、立ち寄り利用)が行われるなど、 従来の図書館ではみられなかった多様な利用形態が見られるように なった。これら来館者の利用行動は、複合された施設の性格や空間 相互のつながりに影響を受けることから、複合公立図書館の計画に
あたっては、来館目的と利用空間のつながりに着目した利用実態の 解明が極めて重要であると考える。

公共図書館を対象にした既往研究は多岐にわたるが、近年の動向 に注目すると、管理・運営実態については 1990 年代以降の複合型 図書館を対象にその空間構成を総括したうえで職員の管理面積、業 務量、職掌状況から管理・運営の実態を明らかにし、設計者と運営 者の関わり方をもとに計画プロセスについてとらえた研究文 2),3) な どがある。また施設複合化の状況については、全国の複合公立図書 館を対象に、その設置動向や自治体の状況、複合パターン、複合化 の図書館利用への影響をとらえた研究文 4) などがある。来館者の利 用行動については、貸出型利用から滞在型利用への利用傾向の変化 を踏まえたうえで利用者の属性と座席選択をもとに近年の図書館の 利用実態をとらえた研究文 5) や、滞在型図書館における来館者の移 動経路と活動の分布をとらえ、空間構成との関係について分析を行 った研究文 6) などがある。特についで利用については、図書館と公 共施設との複合施設を対象に利用行為の傾向や施設構成、室の開放 度合等の側面からその利用実態をとらえた研究文7) があるが、管理 方式を踏まえた上で利用者の来館目的の有無に基づく利用行動や利 用空間とのつながりについて分析した研究は十分行われていない。
*1 九州大学大学院人間環境学研究院 助教 ·博士 (工学)

*2 鹿島建設(侏)

*3 九州大学大学院人間環境学府空間システム専攻 修士課程
Assist. Prof., Faculty of Human-Environment Studies, Kyushu Univ., Dr.Eng. Kajima Corporation

Grad. Student, Graduate School of Human-Environment Studies, Kyushu Univ. 
そこで本研究では、指定管理者制度導入後の 2003 年以降に新設 または改修された複合公立図書館を対象に、施設利用者の来館目的 をもとに利用行動をとらえることで、今後の複合公立図書館の計画 に資する知見を得ることを目的とする。

\section{2. 研究の方法}

\section{2-1. 調査対象}

本研究では図書館の統計資料文 8) をもとに、施設台帳や建築雑誌 等より図面情報が収集可能な事例のうち 2003 年から 2018 年まで に新設または改修された全国の複合公立図書館で、最寄りの駅から $2 \mathrm{~km}$ 圏内にあり調査協力が得られた 48 館を対象とした (Table1)。

Table1 Libraries included in the research

\begin{tabular}{|c|c|c|c|c|c|}
\hline $\begin{array}{l}\text { Location } \\
\text { (Prefecture) }\end{array}$ & Name & $\begin{array}{l}\text { Opening } \\
\text { monthandyear }\end{array}$ & $\begin{array}{c}\text { Total floor } \\
\text { area* }\end{array}$ & $\begin{array}{l}\text { Distance from } \\
\text { the station }\end{array}$ & Management \\
\hline Fukui & F i Library & Feb. 2003 & $14,297 \mathrm{~m}^{2}$ & $1.30 \mathrm{~km}$ & Designated \\
\hline Ibaraki & Yk Library & May 2004 & $4,135 \mathrm{~m}^{2}$ & $0.10 \mathrm{~km}$ & Designated \\
\hline Mie & Kn Library & Oct.2004 & $3,169 \mathrm{~m}^{2}$ & $0.55 \mathrm{~km}$ & PFI \\
\hline Saitama & Sg Library & Mar. 2006 & $2,108 \mathrm{~m}^{2}$ & $1.50 \mathrm{~km}$ & Direct \\
\hline Iwate & It Library & May 2006 & $10,590 \mathrm{~m}^{2}$ & $0.50 \mathrm{~km}$ & Designated \\
\hline Tokyo & Ts Library & Jul. 2007 & $3,065 \mathrm{~m}^{2}$ & $0.22 \mathrm{~km}$ & Direct \\
\hline Fukuoka & Um Library & Sep. 2007 & $1,777 \mathrm{~m}^{2}$ & $0.55 \mathrm{~km}$ & Direct \\
\hline Fukushima & I k Library & Oct. 2007 & $8,602 \mathrm{~m}^{2}$ & $0.20 \mathrm{~km}$ & Direct \\
\hline Osaka & Sy Library & Jan. 2008 & $1,667 \mathrm{~m}^{2}$ & $0.55 \mathrm{~km}$ & Designated \\
\hline Hiroshima & Fs Library & Jul. 2008 & $4,812 \mathrm{~m}^{2}$ & $1.10 \mathrm{~km}$ & Direct \\
\hline Aichi & Ok Library & Nov. 2008 & $7,895 \mathrm{~m}^{2}$ & $0.85 \mathrm{~km}$ & Direct \\
\hline Iwate & Of Library & Nov. 2008 & $1,843 \mathrm{~m}^{2}$ & $1.10 \mathrm{~km}$ & Direct \\
\hline Shizuoka & Fe Library & Feb. 2009 & $3,300 \mathrm{~m}^{2}$ & $0.45 \mathrm{~km}$ & Direct \\
\hline Yamaguchi & Ss Library & Mar. 2010 & $4,074 \mathrm{~m}^{2}$ & $0.80 \mathrm{~km}$ & Direct \\
\hline Yamagata & My Library & May 2010 & $1,226 \mathrm{~m}^{2}$ & $0.50 \mathrm{~km}$ & Direct \\
\hline Nagano & Si Library & Jul. 2010 & $3,286 \mathrm{~m}^{2}$ & $0.65 \mathrm{~km}$ & Direct \\
\hline Tokyo & Ko Library & Nov. 2010 & $686 \mathrm{~m}^{2}$ & $0.35 \mathrm{~km}$ & Private \\
\hline Tokyo & Kk Library & Apr. 2011 & $577 \mathrm{~m}^{2}$ & $0.21 \mathrm{~km}$ & Outsourced \\
\hline Gunma & Ts Library & Apr.2011 & $5,460 \mathrm{~m}^{2}$ & $1.40 \mathrm{~km}$ & Direct \\
\hline Tokyo & Mp Library & Jul. 2011 & $3,324 \mathrm{~m}^{2}$ & $0.22 \mathrm{~km}$ & Designated \\
\hline Fukushima & Sk Library & Jul. 2011 & $2,732 \mathrm{~m}^{2}$ & $0.30 \mathrm{~km}$ & Direct \\
\hline Tokyo & Hy Library & Nov. 2011 & $3,665 \mathrm{~m}^{2}$ & $0.40 \mathrm{~km}$ & Designated \\
\hline Akita & Yh Library & Dec. 2011 & $2,705 \mathrm{~m}^{2}$ & $0.50 \mathrm{~km}$ & Direct \\
\hline Toyama & Yt Library & Jun. 2012 & $1,200 \mathrm{~m}^{2}$ & $0.10 \mathrm{~km}$ & Direct \\
\hline Miyagi & Mn Library & Oct. 2012 & $2,810 \mathrm{~m}^{2}$ & $0.12 \mathrm{~km}$ & Direct \\
\hline Yamanashi & Yn Library & Nov. 2012 & $10,555 \mathrm{~m}^{2}$ & $0.23 \mathrm{~km}$ & Direct \\
\hline Saga & To Library & Apr. 2013 & $3,046 \mathrm{~m}^{2}$ & $1.00 \mathrm{~km}$ & Designated \\
\hline Oita & Oi Library & Jul. 2013 & $4,548 \mathrm{~m}^{2}$ & $0.75 \mathrm{~km}$ & Direct \\
\hline Tokyo & Tk Library & Aug. 2014 & $357 \mathrm{~m}^{2}$ & $0.65 \mathrm{~km}$ & Designated \\
\hline Tokyo & Nm Library & Mar. 2015 & $440 \mathrm{~m}^{2}$ & $0.85 \mathrm{~km}$ & Direct \\
\hline Chiba & Yy Library & Jul. 2015 & $4,860 \mathrm{~m}^{2}$ & $0.90 \mathrm{~km}$ & Designated \\
\hline Aichi & Mh Library & Jul. 2015 & $1,496 \mathrm{~m}^{2}$ & $0.65 \mathrm{~km}$ & Direct \\
\hline Gifu & Gf Library & Jul. 2015 & $9,209 \mathrm{~m}^{2}$ & $1.90 \mathrm{~km}$ & Direct \\
\hline Osaka & Rg Library & Aug. 2015 & $1,381 \mathrm{~m}^{2}$ & $1.00 \mathrm{~km}$ & Designated \\
\hline Toyama & T i Library & Aug. 2015 & $4,620 \mathrm{~m}^{2}$ & $0.10 \mathrm{~km}$ & Direct \\
\hline Tokyo & Kt Library & Sep. 2015 & $1,896 \mathrm{~m}^{2}$ & $0.05 \mathrm{~km}$ & Direct \\
\hline Kanagawa & En Library & Oct. 2015 & $2,556 \mathrm{~m}^{2}$ & $0.65 \mathrm{~km}$ & Direct \\
\hline Nagano & Km Library & Nov. 2015 & $2,150 \mathrm{~m}^{2}$ & $0.40 \mathrm{~km}$ & Direct \\
\hline Miyagi & Tg Library & Mar. 2016 & $3,342 \mathrm{~m}^{2}$ & $0.10 \mathrm{~km}$ & Designated \\
\hline Okayama & Oa Library & Apr. 2016 & $264 \mathrm{~m}^{2}$ & $1.60 \mathrm{~km}$ & Direct \\
\hline Yamagata & Yz Library & Jul. 2016 & $3,048 \mathrm{~m}^{2}$ & $1.70 \mathrm{~km}$ & Designated \\
\hline Tochigi & Mg Library & Jul. 2016 & $1,849 \mathrm{~m}^{2}$ & $0.45 \mathrm{~km}$ & Direct \\
\hline Kanagawa & Ya Library & Nov. 2016 & $6,560 \mathrm{~m}^{2}$ & $0.45 \mathrm{~km}$ & Designated \\
\hline Okayama & Th Library & Feb. 2017 & $2,250 \mathrm{~m}^{2}$ & $0.05 \mathrm{~km}$ & Designated \\
\hline Tokyo & Ak Library & Mar. 2017 & $10,944 \mathrm{~m}^{2}$ & $0.21 \mathrm{~km}$ & Direct \\
\hline Gunma & Ob Library & Apr. 2017 & $1,050 \mathrm{~m}^{2}$ & $0.10 \mathrm{~km}$ & Direct \\
\hline Miyagi & Os Library & Jul. 2017 & $3,855 \mathrm{~m}^{2}$ & $0.80 \mathrm{~km}$ & Direct \\
\hline Yamaquchi & St Library & Feb. 2018 & $2,374 \mathrm{~m}^{2}$ & $0.00 \mathrm{~km}$ & Designated \\
\hline
\end{tabular}

* The total floor area covers only the library section, excluding some target buildings

\section{2-2. 調查方法}

調査では、まず前述の調査対象館を対象に施設台帳や建築雑誌か ら収集した各種図面などをもとにした資料調査および図書館管理者 を対象とした運営方針や利用状況に関するアンケート調査注 2) を行 い、複合公立図書館の管理状況について把握した。

さらにこれらのうち、機能複合化による利用者増加への期待、駅 前等利便性の高い立地など積極的な理由から複合化され、特徵的な 計画が行われた施設 2 館を抽出し、来館者に対するアンケート調査
および施設利用者を対象とした巡回観察調查を行うことでその利用 実態を明らかにした（Table2,3、Fig.1）。

Table2 Survey outline

\begin{tabular}{|c|c|c|c|}
\hline Investigation & $\begin{array}{l}\text { Survey } \\
\text { period }\end{array}$ & $\begin{array}{c}\text { Number } \\
\text { of libraries }\end{array}$ & Survey outline \\
\hline $\begin{array}{l}\text { Document } \\
\text { survey }\end{array}$ & $\begin{array}{c}\text { Apr-Sep. } \\
2018\end{array}$ & 48 & $\begin{array}{l}\text { Understood the characteristics of the plan } \\
\text { from the technical proposals, facility ledgers, } \\
\text { and implementation drawings for the } \\
\text { complex public libraries nation wide } \\
\text { established or renovated after } 2003\end{array}$ \\
\hline $\begin{array}{l}\text { Questionnaire } \\
\text { survey 1: } \\
\text { Administrator } \\
\text { questionnaire }\end{array}$ & $\begin{array}{c}\text { Sep-Oct. } \\
2018\end{array}$ & 43 & $\begin{array}{l}\text { Conducted a questionnaire survey among } \\
\text { library managers regarding facility } \\
\text { management policies and usage status to } \\
\text { understand management status }\end{array}$ \\
\hline $\begin{array}{l}\text { Questionnaire } \\
\text { survey 2: } \\
\text { User questionnaire }\end{array}$ & $\begin{array}{c}\text { Oct-Nov. } \\
2018\end{array}$ & 2 & $\begin{array}{l}\text { Conducted a questionnaire survey on the } \\
\text { usage status of the facility with respect to } \\
\text { visitors to understand its characteristics }\end{array}$ \\
\hline $\begin{array}{l}\text { Observation } \\
\text { survey }\end{array}$ & $\begin{array}{c}\text { Oct-Nov. } \\
2018\end{array}$ & 2 & $\begin{array}{l}\text { Patrolled the pre-planned route at } \\
30 \text {-minute intervals, and plotted the } \\
\text { distribution and behavior of users in each } \\
\text { area on a plan view }\end{array}$ \\
\hline
\end{tabular}

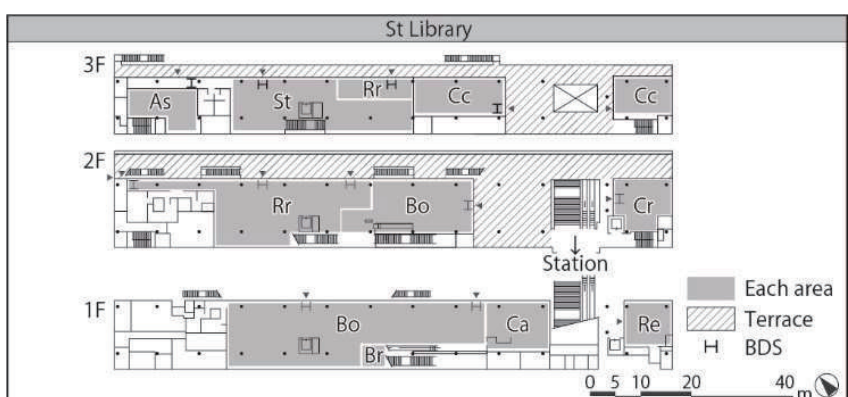

\begin{tabular}{|l|l|l|l|l|l|}
\hline Site area & $4,935 \mathrm{~m}^{2}$ & Opening date & Feb. 2018 & Collection of books & 67,000 \\
\hline
\end{tabular} $\begin{array}{lllllll}\text { Building area } & 3,811 \mathrm{~m}^{2} & \text { Floor number } & 3 \mathrm{~F} & \text { Administrator } & \mathrm{C} \mathrm{CO} \text {. }\end{array}$ Total floor area $9,421 \mathrm{~m}^{2}$ Main structure Steel-framed New or renovated New Tg Library

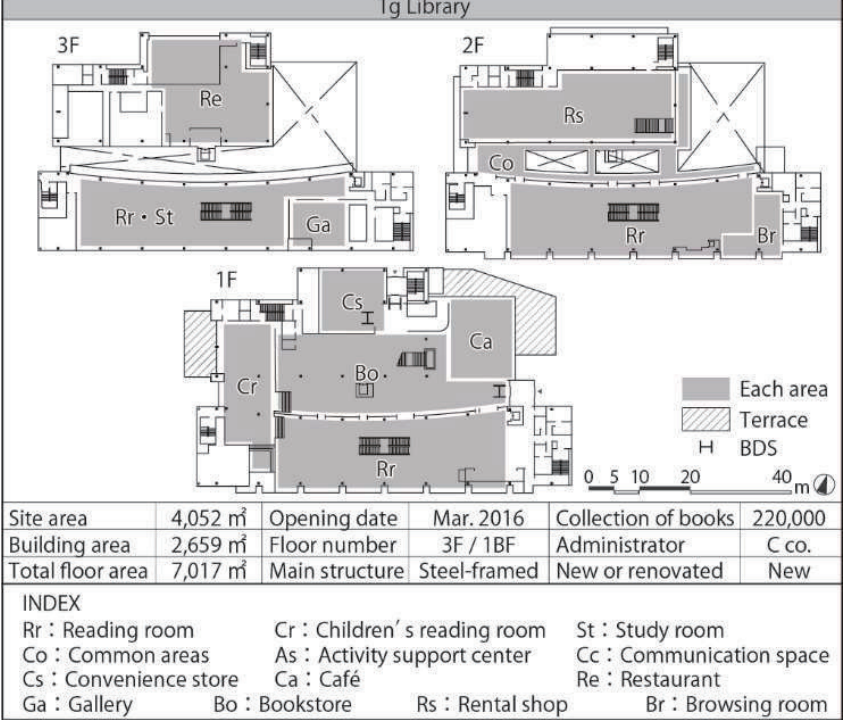

Cs: Convenience store $\mathrm{Ca}:$ Cafe
$\mathrm{Ga}:$ Gallery $\quad$ Bo : Bookstore : Rental shop $\mathrm{Br}$ : Browsing room

Fig.1 Overview of the surveyed building

Table3 Summary of fact-finding survey

\begin{tabular}{|c|c|c|c|c|}
\hline & \multicolumn{2}{|c|}{ St Library } & \multicolumn{2}{|c|}{ Tg Library } \\
\hline Survey date & Oct. 28th Sun & Oct. 29th Mon & Nov. 11th Sun & Nov. 12th Mon \\
\hline Number of seats & \multicolumn{2}{|c|}{406 seats } & \multicolumn{2}{|c|}{434 seats } \\
\hline $\begin{array}{c}\text { Survey time } \\
\text { (Opening hours) }\end{array}$ & \multicolumn{2}{|c|}{$\begin{array}{c}10: 00-21: 00 \\
(09: 30-22: 00)\end{array}$} & \multicolumn{2}{|c|}{$\begin{array}{c}09: 30-20: 00 \\
(09: 00-21: 30)\end{array}$} \\
\hline Number of respondents & 115 people & 116 people & 111 people & 111 people \\
\hline Number of rounds & \multicolumn{2}{|c|}{18 times } & \multicolumn{2}{|c|}{17 times } \\
\hline Number of visitor plots & 2,493 people & 1,845 people & 3,332 people & 2,630 people \\
\hline
\end{tabular}

\section{2-3. 分析方法}

研究にあたり、まず全調査対象館を対象に図書館と複合化される 他施設の床面積の割合および 1 館中に複合化される施設の機能構成 とその割合を分析し、空間面から近年の複合化の傾向をとらえた。 
次に、調査対象館の管理者を対象に管理方式別にその運営方針の分 析を行い、公立複合図書館における運営面での特徴をとらえた。以 上より近年の複合公立図書館の運営面、空間面での特徴をとらえた 上で、同一の民間企業注 3) が指定管理者であり、その両面において 近年先進的な取り組みを行う $\mathrm{St} 、 \mathrm{Tg}$ 館注 4) を対象に具体的な利用実 態をとらえた。

$\mathrm{St} 、 \mathrm{Tg}$ 館の利用実態調查では、まず来館者の利用行動の時間变化 を主要空間別にとらえた上で、施設利用者の来館目的の有無と内容、 ついで利用のパターンと展開、立ち寄り利用者の利用空間の広がり をとらえることで、滞在型利用の起点となる利用構造を明らかにし た。なお、 $\mathrm{St} 、 \mathrm{Tg}$ 館はともに駅からの距離が極めて近い公立複合図 書館であるが、St 館は駅と直結した施設である。

Table4 Classification of complex functions

\begin{tabular}{|c|c|c|}
\hline \multicolumn{2}{|c|}{ Classification } & Specific function \\
\hline \multirow{5}{*}{$\begin{array}{l}\text { Commercial/ } \\
\text { Industrial }\end{array}$} & Retail / Merchandise & Store \\
\hline & Eating / Drinking & Restaurant/Cafe \\
\hline & Center / Chamber & $\begin{array}{l}\text { Industrial support center / } \\
\text { Chamber of commerce }\end{array}$ \\
\hline & Business & Office \\
\hline & Amusement & Movie theater \\
\hline \multirow[t]{2}{*}{ Social education } & Culture / Learning & $\begin{array}{l}\text { Halls / Theaters / Planetariums / } \\
\text { Public halls / Lifelong learning } \\
\text { center / Community center }\end{array}$ \\
\hline & Storage / Exhibition & Gallery/ Museum/ Exhibition \\
\hline \multirow[b]{2}{*}{ Government } & Ministries & City hall / Ward office \\
\hline & Administration & $\begin{array}{l}\text { Citizen service center / } \\
\text { Activity support center }\end{array}$ \\
\hline \multirow{3}{*}{ Child welfare } & Children's / Infants & $\begin{array}{c}\text { Children's house / Daycare center / } \\
\text { Nursery / Nursery school }\end{array}$ \\
\hline & Child care support & Child-rearing support center \\
\hline & Youth support & Youth support center \\
\hline \multirow{2}{*}{ Medical / Health } & Health & Health center \\
\hline & Medical & Clinic \\
\hline \multicolumn{2}{|c|}{ Social welfare } & Welfare center for the disabled \\
\hline School education & Schools & $\begin{array}{c}\text { Elementary school / Satellite campus / } \\
\text { University related facilities }\end{array}$ \\
\hline \multicolumn{2}{|c|}{ Residential } & Housing \\
\hline \multicolumn{2}{|c|}{ Transportation } & Station / Bus center \\
\hline
\end{tabular}

\begin{tabular}{|l|l|}
\hline Proportion of functions in complex facilities & Number of complex functions in complex facilities \\
\hline
\end{tabular}

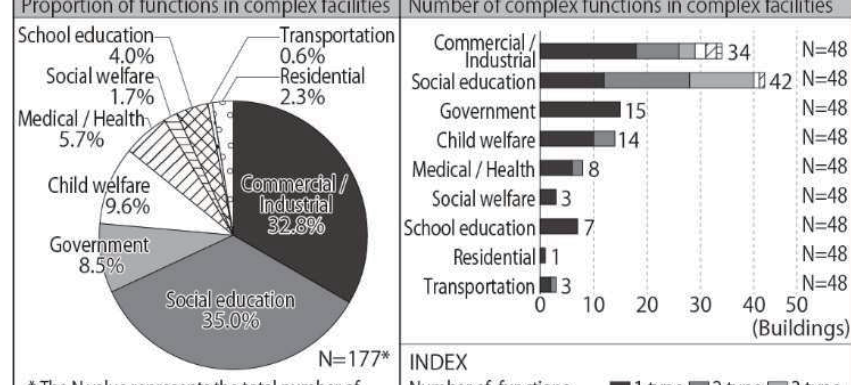
* The N value represents the total number of $\quad$ Number of functions $\quad \square 1$ type $\square 2$ type $\square 3$ type facilities complexed in the 48 surveyed libraries $\quad$ combined in one building $\square 4$ type $\square \geq 5$ type $\boxminus 6$ type Fig.2 Proportion of complex functions

\section{3. 複合施設の機能構成とその割合}

全調查対象館 48 館を対象とした資料調查をもとに、対象館に複 合して設置された施設機能の延べ総数の割合についてみると、商業・ 産業施設と社会教育施設の 2 分類が全体の約 7 割を占める。その内 訳として商業・産業施設では飲食店が、社会教育施設ではホールや 生涯学習センターなどを含む文化・学習施設が半数以上を占めてお り、近年では飲食店のように来館者が気軽に利用しやすい空間やホ ールなどの大空間を要する公共施設と複合する傾向にあることがう かがえる。一方、同じ大分類に含まれる機能が複数複合されている 館もあるため、それらの複合数を大分類別にみると、商業・産業施 設、社会教育施設、児童福祉施設、医療・保健施設、交通施設にお
いて複数の機能を複合している。中でも商業・産業施設と社会教育 施設は同じ大分類内に複合されている機能数が多く、最も多いもの で前者は店舗やカフェ、オフィス、産業支援センター等 6 種類を含 むもの、後者はホールやプラネタリウム、ギャラリー等 5 種類の機 能が複合されているものもみられた（Table4、Fig.2）。

\section{4. 複合公立図書館における運営方針の傾向}

近年の複合公立図書館の運営方針の傾向をとらえるため、全調查 対象館のうち、協力の得られた 43 館への管理者アンケートをもと に、館の運営方針を貸出指向、課題解決注 5) 指向、滞在注 6) 指向の 3 項目に分類し、それらの傾向について分析を行った。

まず全体の傾向として、課題解決指向の項目では［レファレンス 機能の充実］と［地域の発展を支える情報拠点であること］を 6 割 以上の図書館が重視している。また滞在指向の項目では、[利用者が 居心地のいい空間づくり］、[複合した他施設と連携したサービスの 提供］、[市民の交流の場］を約 6〜7 割の図書館が重視しているこ とが分かった。一方で貸出指向の項目では、最も多い[自動貸出機 の導入]でも 4 割強であり、[貸出冊数の向上]については 3 割強 にとどまっている。

Table5 Definition of library management policy

\begin{tabular}{|c|c|c|}
\hline $\begin{array}{l}\text { Management } \\
\text { policy }\end{array}$ & Definition & Questionnaire items \\
\hline $\begin{array}{l}\text { Lending- } \\
\text { oriented }\end{array}$ & $\begin{array}{l}\text { A library that emphasizes the } \\
\text { provision of books citizens } \\
\text { require and focuses on } \\
\text { lending }\end{array}$ & $\begin{array}{l}\text { - Increasing the number of books for lending } \\
\text { - Introducing an automatic lending machine } \\
\text { - Introducing a reading passbook }\end{array}$ \\
\hline $\begin{array}{l}\text { Problem solving- } \\
\text { oriented }\end{array}$ & $\begin{array}{l}\text { A library that provides various } \\
\text { materials and information so } \\
\text { that these can be used } \\
\text { effectively, and support } \\
\text { problem solving and people's } \\
\text { efforts toward that }\end{array}$ & $\begin{array}{l}\text { - Enhancing the reference function } \\
\text { - Cooperating with other libraries } \\
\text { - Providing lifelong learning services } \\
\text { - Supporting regional development } \\
\text { - Providing magazine or newspaper articles } \\
\text { - Enhancing search equipment }\end{array}$ \\
\hline $\begin{array}{c}\text { Stay- } \\
\text { oriented }\end{array}$ & $\begin{array}{l}\text { A library anyone can visit } \\
\text { easily and spend a long time } \\
\text { in comfortably while enjoying } \\
\text { its various services }\end{array}$ & $\begin{array}{l}\text { - Creating a comfortable space for users } \\
\text { - Providing enhanced reading seats } \\
\text { - Having large open bookshelves and reading rooms } \\
\text { - Selecting furniture that is comfortable for users } \\
\text { - Providing services linked to other complex facilities } \\
\text { - Adopting a unique book classification method } \\
\text { - Becoming a place for interaction for citizens }\end{array}$ \\
\hline
\end{tabular}

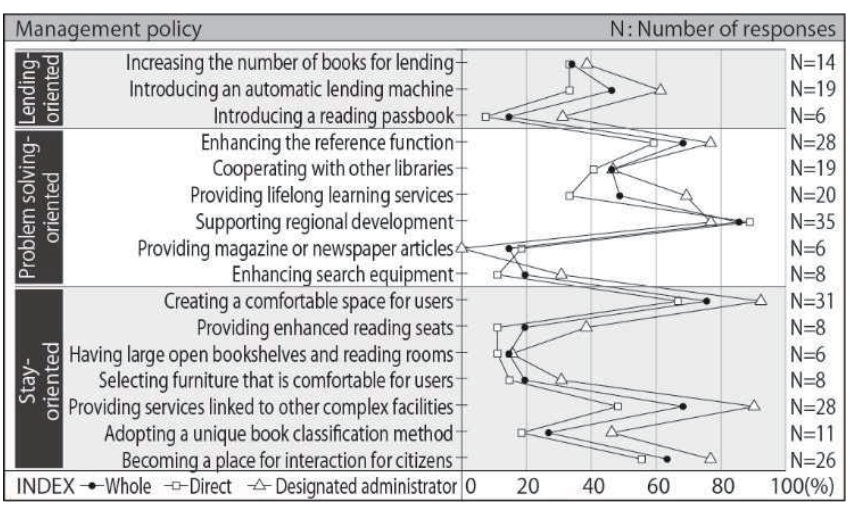

Fig.3 Management method and management policy trends

次に管理方式別にみると、直営方式を採用している図書館は大半 の項目で全体より割合が低く、貸出指向の項目では［自動貸出機の 導入]、課題解決指向の項目では [生涯学習サービスの提供]、滞在 指向の項目では［複合した他施設と連携したサービスの提供］が全 体に比べ特に割合が低くなっている。一方、課題解決指向の [地域 の発展を支える情報拠点であること］と［雑誌記事、新聞記事の提 
供］の 2 項目は全体に比べ割合が高くなっており、中でも前者は全 体でもその割合が高い項目となっている。

指定管理者方式を採用している図書館では、大半の項目で全体よ り割合が高く、特に貸出指向の項目では [自動貸出機の導入］と [読 書通帳の導入]、課題解決指向の項目では [生涯サービスの提供 $] 、$ 滞在指向の項目では [利用者が居心地のいい空間づくり］、[閲覧席 の充実］、[複合した他施設と連携したサービスの提供］が全体に比 べ特に割合が高くなっている。中でも［利用者が居心地のいい空間 づくり］と［複合した他施設と連携したサービスの提供］は全体で もその割合が高い項目となっている。

項目ごとに運営方針の傾向をみると、自動貸出機の導入は直営方 式の図書館の約 3 割、指定管理者方式の図書館の約 6 割が重視して いる。この指定管理者が運営する図書館 8 館のうち 6 館がレファレ ンス機能の充実と生涯学習サービスの提供の両方を重視しているこ とから、貸出業務の自動化により職員の労力を低減し、課題解決に つながる充実したサービスの提供を試みていることがうかがえる。 一方、施設全体の出入口に BDS を設置している図書館 12 館のうち 8 館が複合施設との連携を重視しており、複合施設同士をつなぐ吹 抜けや複数の機能が一体化した空間構成等の特徵が共通してみられ る (Table5、Fig.3)。

\section{5. 利用実態の分析}

\section{5-1. 主要空間別に見た来館者の座席利用}

$\mathrm{St}, \mathrm{Tg}$ 館を対象に平日休日の開館時間における 30 分おきの巡回 観察調査をもとに、主要空間別の来館者の座席利用について分析を 行った。なお、座席利用の変動が極端に多くなる昼食時間帯 $(11: 30$ 〜13:00)、夕食時間帯 $(16: 30 \sim 18: 00)$ は調査から除外している注7)。

St 館では、平日休日とも閲覧エリアで読書、学習室で勉強、書店 やカフェで休息目的での座席利用が多くみられた。2 階閲覧室は平 日休日ともに昼過ぎの $14: 00$ 頃に利用のピークを迎えるが、学習室 は平日 19:30、休日 15:00、カフェは平日 16:30、休日 15:00 と曜日 によってピークの時間帯が異なる。特に 2 階閲覧室は平日はピーク 時でも満席にはならず、時間ごとの座席利用者数の変動も緩やかで ある。休日はピーク時がほぼ満席であるのに対し、18:00 以降の座 席利用者数は少なく一日の変動が大きい。学習室は平日休日ともピ 一ク時前後の時間帯でほぼ満席の状態が続くが、平日の $16: 30$ 以降 は 10:00 16:00 の時間帯に比べ座席利用者数が増加し、休日の 18:00 以降は 10:00〜 16:30 の時間帯に比べ座席利用者数が減少す る。カフェは休日のピーク時前後でほぼ満席の状態であるがその他 の時間帯は変動も緩やかである。ただし、平日は 18:00 以降座席利 用者数が緩やかに減少するのに対し、休日は夕方も一定の座席利用 者数を維持している。その他、休日において 2 階部分で休息目的で の座席利用が一定数みられるが、これは駅と直結する 2 階部分にベ ンチ席が多く配置されているため、隣接する駅側から来館した利用 者が、その場所で会話やスマートフォンを使用する等の行為がとり やすいためと考えられる注 8 )。

$\mathrm{Tg}$ 館では、平日休日とも閲覧エリアで読書と休㮩、学習室とカウ ンター席のある共用部で勉強、カフェで休息目的による座席利用が 多くみられた。1階閲覧室は平日 14:30、休日 13:00の昼過ぎ頃、2 階閲覽室は平日 16:00、休日 14:00 の夕方頃の時間帯にピークを迎

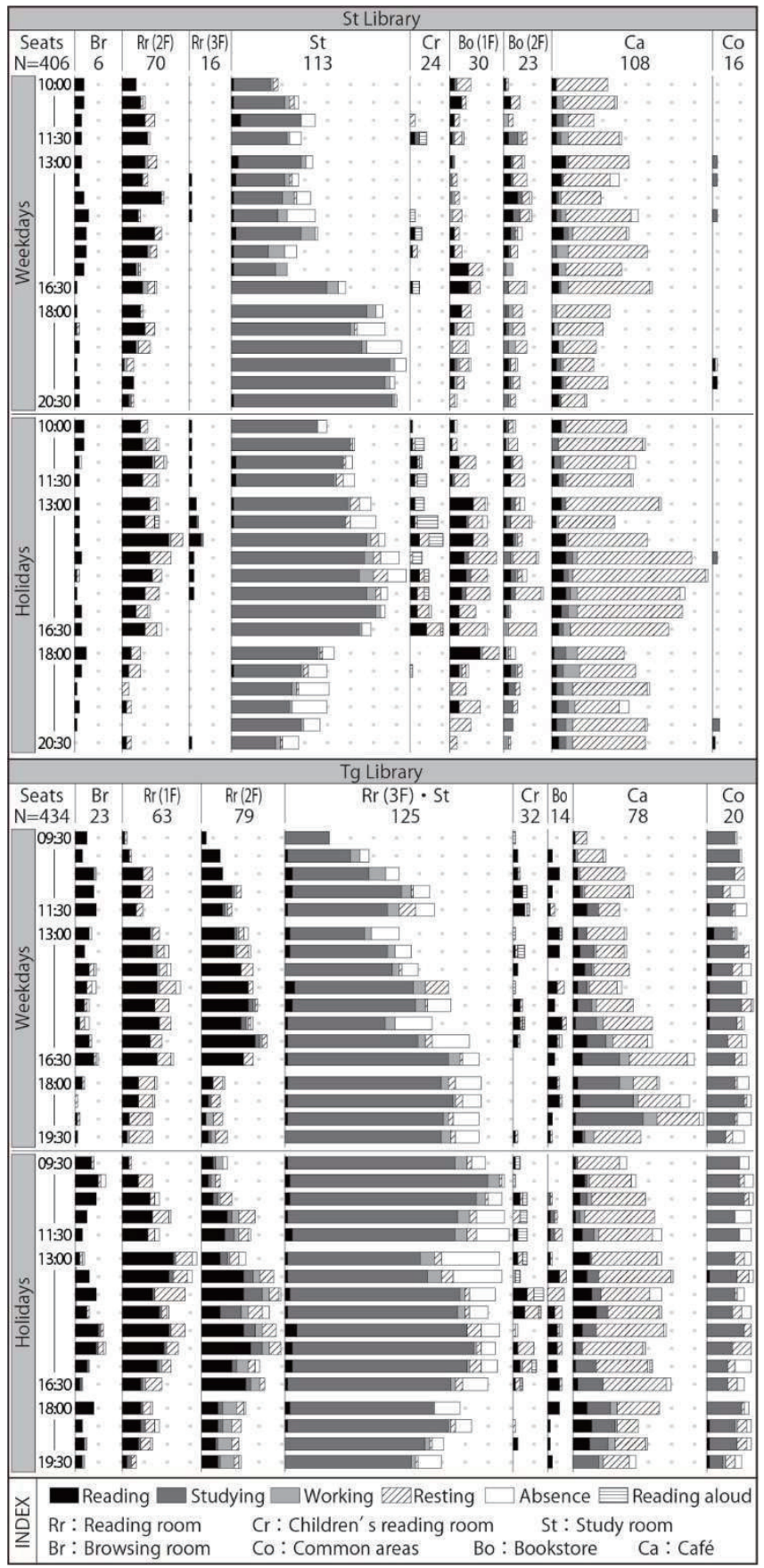

Fig.4 Development of behavior based on seat usage

えるが、3 階閲覧・学習室は平日 18:00、休日 11:30、カフェは平日 19:00、休日 13:30 と、St 館同様曜日によってピークの時間帯が異 なる。ただし、St 館に比べ平日は遅い時間帯、休日は早い時間帯か らの利用が見られる。1、2 階閲覧室は平日休日ともにピークの時間 帯には満席に近い座席利用者数となるが、開館後間もない午前の時 間帯と 18:00 以降の夕方の時間帯の利用者数が少ない。なお、夕方 の 1 階閲覧室を中心に休息目的での座席利用が一定数見られるのは、 同エリアにソファ席が多く配置され、利用者がくつろげる空間が積 極的に用意されているためと考えられる。学習室は、平日のピーク 時前後と休日の夕方を除くすべての時間帯でほぼ満席状態が続いて おり、平日 16:00 以降と休日には椅子席の多いカフェや 2 階閲覧工 リアに勉強目的のあふれ出しによる座席利用者が広がっている。さ 
らにカフェは、前述の学習室からのあふれ出しが発生する平日夕方 以降の時間帯を除くと座席利用者数の変動は緩やかであるが、休日 は学習室からのあふれ出し利用を含め、昼前から夕方まで満席に近 い座席利用者数がある注9) (Fig.4)。

\section{5-2. 施設利用者の来館目的}

$\mathrm{St}, \mathrm{Tg}$ 館の巡回観察調查同日に来館者へのアンケート調查注 ${ }^{10)} を$ 行い、平日休日別に施設利用者の来館目的の分析を行った。来館目 的の分析注 ${ }^{11)}$ にあたり、その目的を解決、閲覧、環境、休息、限定、 その他の 6 種類に分類して分析を行った（Table6）。

Table6 Definition of purpose of visit

\begin{tabular}{|c|c|c|}
\hline Purpose & Definition & Questionnaire items \\
\hline $\begin{array}{c}\text { Problem } \\
\text { solving }\end{array}$ & To read books, or solve what they want to & $\begin{array}{l}\text { - There are books they want to read } \\
\text { - There is something to look for }\end{array}$ \\
\hline Browsing & $\begin{array}{l}\text { To search for and read a book after visiting the } \\
\text { museum, without any fixed book in mind }\end{array}$ & $\begin{array}{l}\text { - To find a book } \\
\text { - To read a book } \\
\text { - To read newspapers or magazines }\end{array}$ \\
\hline $\begin{array}{l}\text { Environment- } \\
\text { related }\end{array}$ & To be in an environment conducive to studying & - To study \\
\hline Rest & $\begin{array}{l}\text { To spend free time in the librarywhich falls } \\
\text { outside of the library's main function }\end{array}$ & $\begin{array}{l}\text { - To use the café } \\
\text {-To spend free time }\end{array}$ \\
\hline Limited & $\begin{array}{l}\text { To temporarily use the library's functions for } \\
\text { compulsory purposes such as returning books } \\
\text { and participating in events }\end{array}$ & $\begin{array}{l}\text { - To return a book } \\
\text { - To participate in an event }\end{array}$ \\
\hline Miscellaneous & $\begin{array}{l}\text { Other purposes such as sightseeing, rental, and } \\
\text { purchasing }\end{array}$ & - Other purpose \\
\hline
\end{tabular}

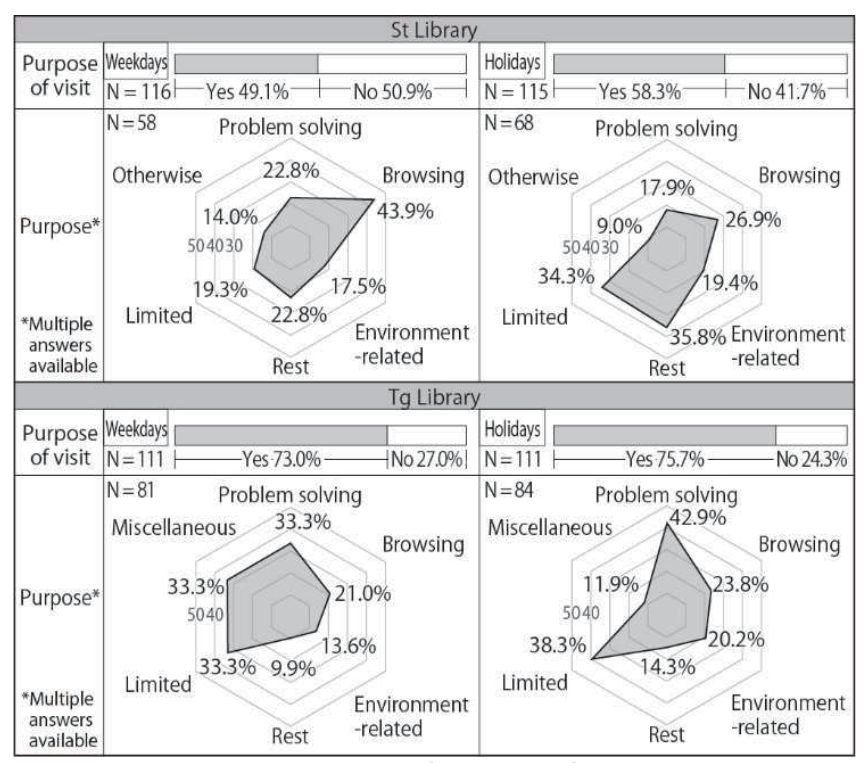

Fig.5 Presence or absence of purpose of visit and its contents

まず $\mathrm{St}$ 館の来館目的の有無についてみると、来館目的をもつ利 用者は平日が $49.1 \%$ 、休日が $58.3 \%$ ありり休日の方が多い。

その内訳をみると、平日は閲覧目的が $43.9 \%$ と最も多い一方で、 次いで解決目的と休息目的がともに $22.8 \%$ となっていることから、 解決目的よりも閲覧を主な目的とした利用が多く行われていること がわかる。一方で休日は休息目的が $35.8 \%$ 、限定目的が $34.3 \%$ と多 く、ともに平日に比べても多い。次いで閲覧目的は $26.9 \%$ となって いるが平日に比べると少なく、解決や閲覽といった目的の利用より もカフェなどでの休息を目的とするものや、イベント参加をはじめ とした特定の目的のための一時的な利用等、図書館の本来的な機能 を直接の目的としない利用が多く行われていることがわかる。

次に $\mathrm{Tg}$ 館では、来館目的をもつ利用者は平日が $73.0 \%$ 、休日が $75.7 \%$ と、両日とも 7 割以上が来館目的をもつ利用者である。
その内訳をみると、平日は解決目的、限定目的、その他が共に $33.3 \%$ と多く、次いで閲覧目的が $21.0 \%$ となっている。同じく休日 では、平日でも多かった解決目的と限定目的での利用がそれぞれ 42.9\%、38.3\%とさらに多くなる一方で、レンタルショップ利用が影 響し平日利用が多かったその他の目的が $11.9 \%$ と最も少なくなって いる。このことから、平日休日ともに解決目的を中心に図書館の本 来的な機能を目的とした利用と、図書の返却や休日のイベント参加 を目的とした利用が多く行われていることがわかった（Fig.5）。

\section{5-3. 来館目的とついで利用とのつながり}

$\mathrm{St}, \mathrm{Tg}$ 館の来館者へのアンケート調查をもとに、当初来館目的と した施設以外の利用と展開をとらえ、来館目的とついで利用とのつ ながりについて分析を行った。

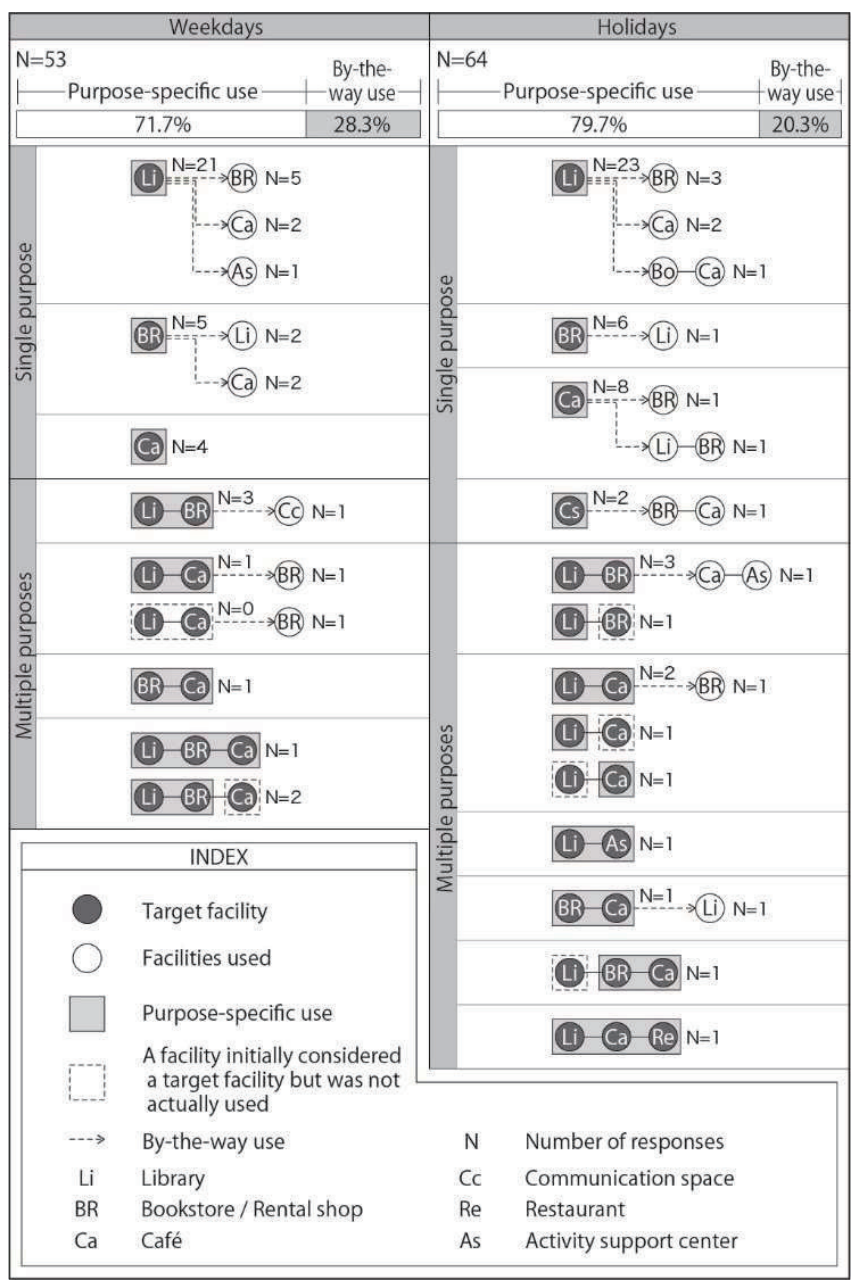

Fig.6 Target facilities for visiting and by-the-way use (St Library)

来館者が当初利用する目的で来館した施設 (以下、目的施設) と、 実際の施設利用（以下、目的内利用）についてみると、St 館では目 的内利用は平日 $71.7 \%$ 、休日 $79.7 \%$ と来館目的があり来館した来館 者の施設利用全体の 7 ～割を占め、平日よりも休日の方が多い。 次にそれぞれの内訳をみると、目的内利用は平日で単独目的が 3 パ ターン、複数目的が 5 パターン注 12) 計 8 パターン、休日で単独目的 が 4 パターン、複数目的が 9 パターン計 13 パターンあり、平日休 日ともに図書館を単独で利用目的としているものが最も多い。一方、 書店・レンタルとカフェの利用は単独目的が多いが、図書館との複 
数目的での利用もみられることから、図書館利用が起点となった利 用展開も起こっているものと考えられる。特に、休日は図書館と他 施設を複数目的としているものが多い。

一方ついで利用についてみると、図書館単独を目的施設としたも ののうち、書店・レンタルをついで利用したものが平日休日ともに 最も多く、カフェや市民活動センター等が続く。平日は当初書店・ レンタルを単独目的とするものが多く、そこから図書館やカフェの 利用に展開しているものも見られた（Fig.6）。

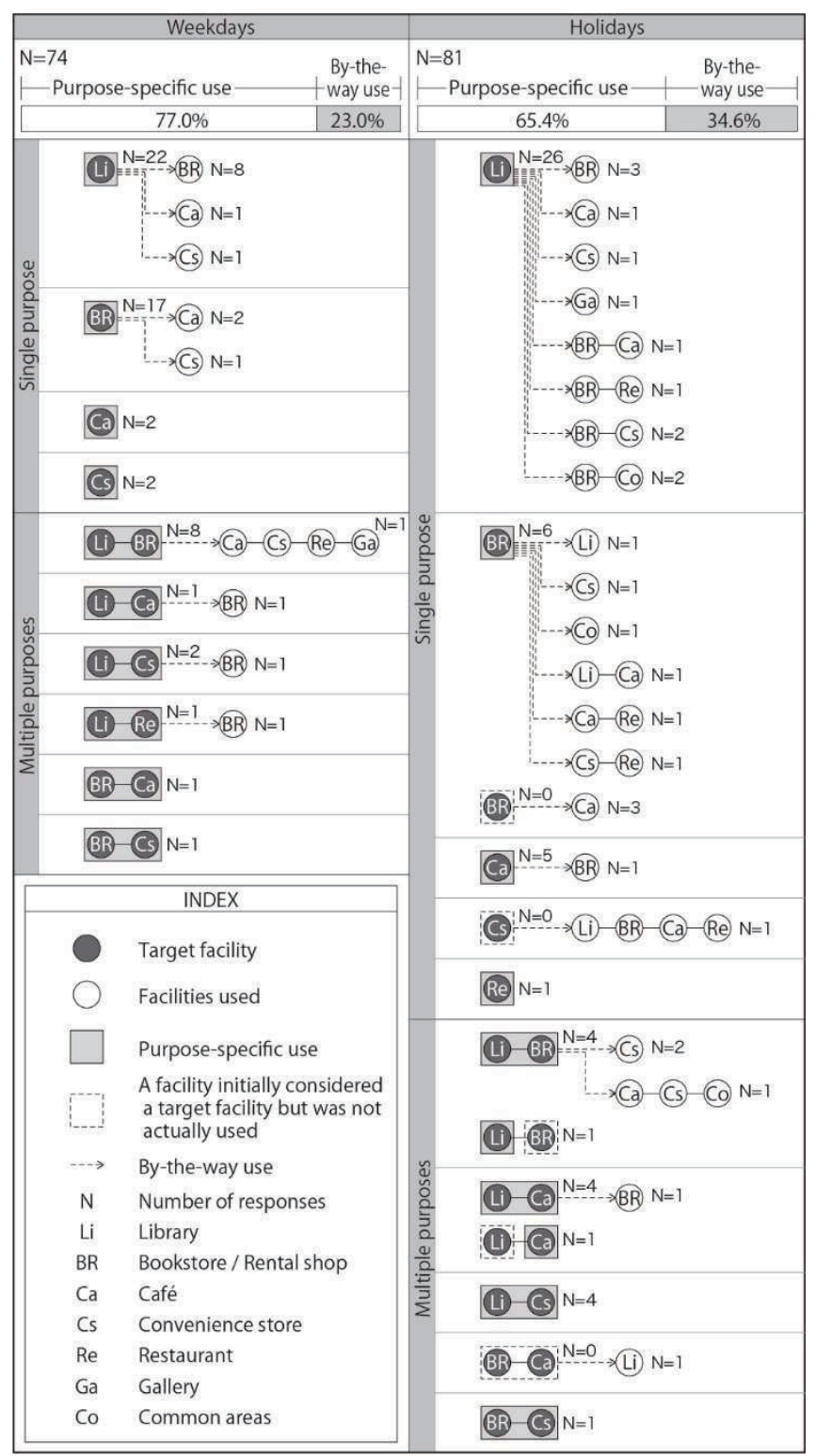

Fig.7 Target facilities for visiting and by-the-way use (Tg Library)

$\operatorname{Tg}$ 館の目的内利用は全体の 6〜 7 割を占めるものの、休日 $65.4 \%$ に対し平日 $77.0 \%$ と休日に比べ平日の方が多く、St館とは逆の利用 状況となっている。次にそれぞれの内訳をみると、目的内利用は平 日で単独目的が 4 パターン、複数目的が 6 パターン計 10 パターン、 休日で単独目的が 4 パターン、複数目的が 6 パターン計 10 パター ンであり、平日休日ともに図書館の単独目的が最も多いが、平日は 書店・レンタルの単独目的も多くみられる。一方、カフェの利用は
平日よりも休日の利用が多く、単独、複数目的ともに同程度の利用 があるが、複数目的のものは特に休日で図書館との組み合わせによ るものが多くみられる。コンビニ利用は少数ではあるが平日休日と もに単独、複数目的両方での利用が見られ、図書館との複数目的に よるものが多いが平日では単独の利用にとどまるものもみられる。

ついで利用についてみると、平日休日ともに図書館を目的施設と するものが多いが、平日は書店・レンタルを目的施設とするものが 多い。図書館を目的施設とするものは、休日ではついで利用に展開 寸るものの数も種類も多い。同様の傾向は書店・レンタルを目的施 設とするものにおいてもみられる。また少数ではあるが、休日にお いて、コンビニを単独で目的施設とする利用が複数施設の利用を伴 うついで利用へ展開するものもみられた（Fig.7）。

\section{5-4. 立ち寄り利用者の利用空間の広がり}

つづいて、 $\mathrm{St}, \mathrm{Tg}$ 館の来館者へのアンケート調査をもとに、特定 の来館目的がない立ち寄り利用者の利用空間の広がりについて分析 を行った。

まず St 館について、立ち寄り利用者が利用した空間数に着目す ると、平日 $66.1 \%$ 、休日 $58.3 \%$ と休日で約 6 割、平日ではそれを超 えて複数空間を利用しており、特に休日は平日に比べ 3 ヶ所以上の 空間の利用者の割合が高く、最大で 5 ヶ所の空間を利用している。 一方、単独空間の利用者は平日 $33.9 \%$ 、休日 $41.7 \%$ 之、休日の割合 が高くなっている。次に、立ち寄り利用者の人数をみると $1 、 2$ 階に 集中している。その内訳を主要空間別に見ると、1 階の書店、2 階の 書店と閲覧室が多く、特に平日はカフェの利用も多くなる。それら の多くが複数空間を利用するものである。1 階書店と 2 階閲覧室は 単一空間利用の割合が他の空間に比べ多くなっているが、これは 1 階書店と 2 階閲覽室がそれぞれ外部から直接アクセスできる出入り 口が設けられており、単独利用がしやすい空間構成となっているか らと考えられる。2 階書店にも出入り口が設けられているが、単独 空間の利用者は他に比べて少ない。このことについて、利用空間の 広がりに着目すると、2 階書店の複数空間利用者は平日休日ともに 1 階書店と 2 階閲覧室のように隣接空間間でのつながりが強い。特 に 2 階閲覧室は異なる機能の空間であっても隣接空間同士であるた め立ち寄り利用によるつながりが強い。一方で 3 階では 3 階閲覧室 を除き、立ち寄り利用者は見られず、学習室として位置付けられて いることや配架書架もビジネス書や専門書等のものが多いこともあ り、立ち寄り利用者の数も $1 、 2$ 階の利用者に比べて極めて少ない。 また、同様の理由から複数空間の利用については、2 階閲覧室だけ でなく、1、2 階書店や 1 階カフェまで広がっている。一方で、3 階 の市民活動支援センターや交流室の立ち寄り利用が見られないのは、 これらの空間がガラスや間仕切壁によって隣接する閲覧エリアと物 理的に仕切られていることなども要因と考えられる。

次に、 $\mathrm{Tg}$ 館の立ち寄り利用が利用した空間数は、平日は $60.0 \%$ 、 休日は $59.3 \%$ 之、両日ともに約 6 割が複数空間を利用しており、平 日は 2 ケ所の空間を利用寸るものが大半であるが、休日では 3 ヶ所 以上の利用割合も多く、最大 10 ヶ所の空間利用も見られる。一方、 単独空間の利用者は平日 $40.0 \%$ 、休日 $40.7 \%$ と両日とも同程度の割 合であった。次に、立ち寄り利用者の人数をみると平日休日ともに 1 階書店の利用者数が多い。その内訳を主要空間別にみると出入り ロがある 1 階のコンビニに対し、1 階の書店の利用が多く、平日休 
日ともに 1 階閲覧室の利用も多い。閲覧室については平日が 1 階の 利用が多いのに対して休日は $1 、 2$ 階ともに多くなり、特に複数空 間利用者の割合も高くなっている。1 階の書店は平日休日ともに単 独利用の割合が他の空間に比べて多くなっているのは、1 階の書店 がメインエントランスに隣接しており単独利用がしやすいことが要 因と考えられる。同様にカフェと 1 階閲覧室も単独利用が多いが、 カフェは休日、1 階閲覧室は平日と、曜日によって異なる傾向を見 せている。コンビニにも図書館へとつながる出入り口があるが、利 用は少数であるものの、そのす心゙てが複数空間利用者となっている。 さらに利用空間の広がりをみると、1 階書店の複数空間利用者は隣 接空間である 1 階閲覧室とのつながりが強く、休日は 2 階閲覧室と のつながりも強い。その他の空間について、利用は少数であるはあ るが複数利用によるものが多く、特に休日は非隣接空間の利用にお けるつながりが施設全体に広がりを見せている（Fig.8）。

\section{6. まとめ}

本報では以下のことを明らかにした。まず近年の複合公立図書館 の機能構成と運営方針について、1）複合施設の機能構成として、文 化・学習施設を中心とした社会教育施設と飲食店を中心とした商業・ 産業施設との複合化がその多くを占め、これらの施設は 1 館中に複 合する機能も他に比べ多いこと。2）運営方針では、地域の情報拠点 としてレファレンス機能の充実を目指寸課題解決指向と施設の複合 化による充実したサービス、居心地のいい空間、交流の場の提供を 目指す滞在指向の方針が重視されている傾向があること。3)このう ち直営方式の図書館では、課題解決指向の中でも地域の情報拠点と しての方針が重視されている一方で、指定管理者方式の図書館では 滞在指向の中でも居心地のいい空間や施設の複合化による充実した サービスの提供を中心とした方針が重視されている傾向があること。

次に、 $\mathrm{St}, \mathrm{Tg}$ 館の施設利用者の来館目的と利用空間のつながりに ついて、4）St、Tg 館ともに平日休日とも閲覧室での読書、学習室
での勉強、カフェでの休㮩による座席利用が多く、閲覧室に対し学 習室とカフェは平日と休日における利用時間帯のピークが異なるこ と。この利用時間帯のピークの違いにより $\mathrm{St}$ 館では隣接する駅側 からの利用者の流入、 Tg 館では学習室からの他の空間への利用者の あふれ出しが見られること。5）施設利用者の来館目的は $\mathrm{St}, \mathrm{Tg}$ 館 ともに休日は限定目的が一定数あるが St 館では図書館の機能を主 目的としない休息目的が多く、 $\mathrm{Tg}$ 館では図書館の本来的な機能を活 用した解決目的が多いこと。6)ついで利用とのつながりについて、 $\mathrm{St}, \mathrm{Tg}$ 館ともに目的内利用の割合が多いが、平日休日のついで利用 ではその割合が逆転していること。特についで利用については、目 的内利用では St 館の場合、複数利用はあくまで図書館利用が起点 となり展開しているのに対し、Tg 館の場合は、図書館利用が主では あるものの、その他施設では単独利用や複数利用のものも多くみら れること。7）さらに、来館目的のない立ち寄り利用について、駅と 直結する $\mathrm{St}$ 館の方が $\mathrm{Tg}$ 館に比べ立ち寄り利用者の割合が高くなっ ていること。また平日休日ともに約 6 割が複数空間を利用しており、 そのつながりとしてメインエントランス階にあり閲覽室に近接した 書籍販売やカフェを起点として展開していること。8）特に立ち寄り 利用者にとって時間的制約が少ない休日においては、利用空間が非 隣接空間にも広がりを見せており、空間の視覚的なつながりがある $\mathrm{Tg}$ 館ではその傾向がより顕著となっていること。

今回の利用実態調查によって明らかになったこれらの傾向はあく まで St、 Tg 館 2 館の調查に基づくものであるため、今後は調查対 象館を増やし、分析をより深めたいと考える。

\section{謝辞}

調查にあたり、各図書館の関係者および来館者の皆さま、各自治 体の職員の方々に多大なるご協力をいただきました。ここに記して 深謝いたします。

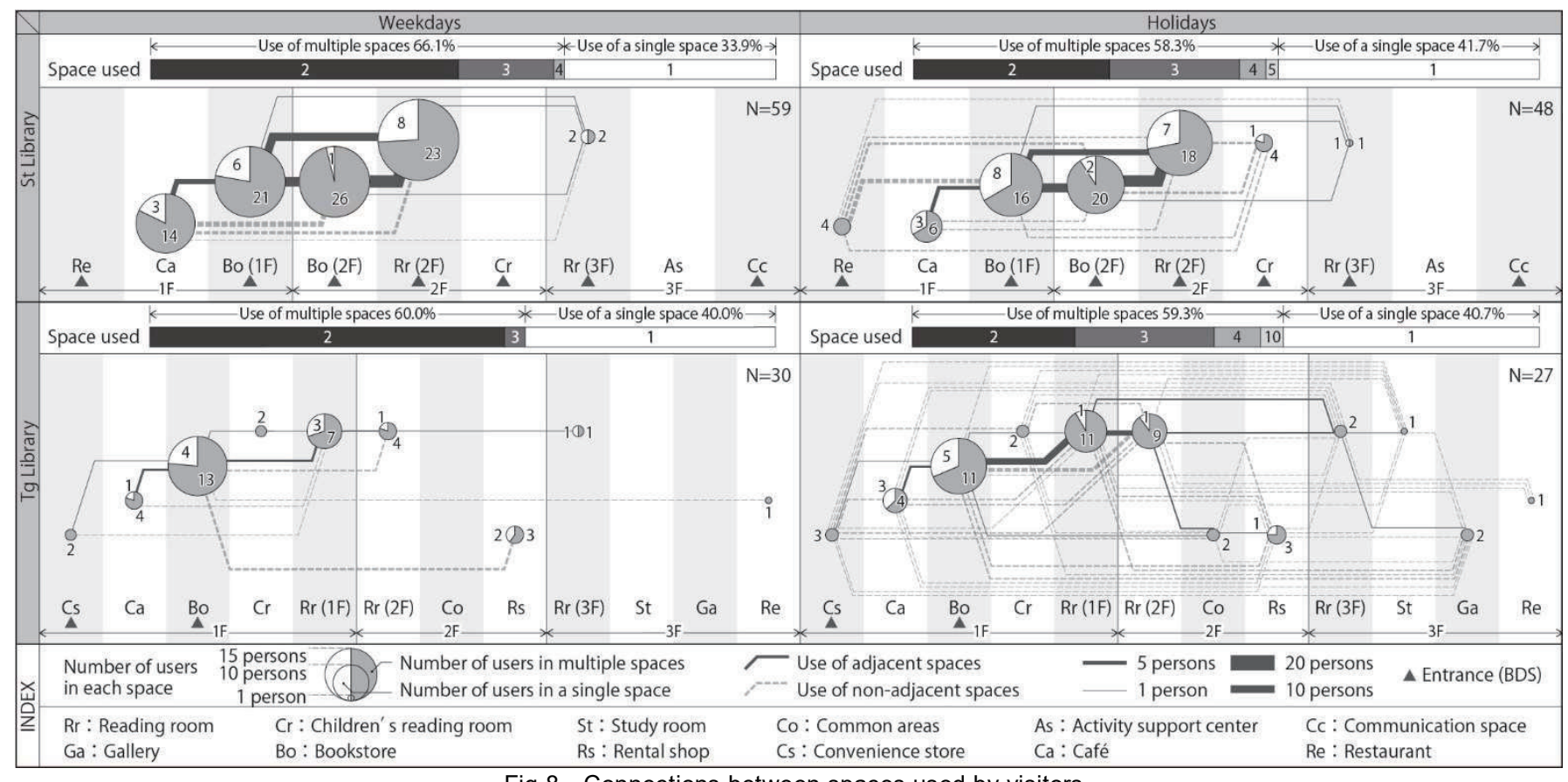

Fig. 8 Connections between spaces used by visitors 
1) Ministry of Education, Culture, Sports, Science and Technology: Interim report on social education survey 2019, 2019.7 (in Japanese)

文部科学省：平成 30 年度社会教育調査中間報告, 2019.7

2) HAGA Mizuho, TSUKUDA Haruka, ONODA Yasuaki: Changes of Facilities and Functional Configuration in Complex Libraries Opened since the 1990s -Study on the Functional Configuration, Management and Planning Processes in Recent Public Libraries vol.1-, Summaries of Technical Papers of Annual Meeting, Architectural Institute of Japan, Architectural Planning and Design, pp. 109-110, 2019.7 (in Japanese)

芳賀瑞穂，佃悠，小野田泰明：1990 年代以降の図書館施設整備実態 の変化と複合型図書館の空間構成 -近年の公共図書館施設整備におけ る計画プロセスとその特徴 その $1-$, 日本建築学会大会学術講演梗 概集，建築計画，pp. 109-110，2019.7

3) ONODA Yasuaki, HAGA Mizuho, TSUKUDA Haruka: Management and Planning Processes in Complex Libraries Opened since the 1990s -Study on the Functional Configuration, Management and Planning Processes in Recent Public Libraries vol.2-, Summaries of Technical Papers of Annual Meeting, Architectural Institute of Japan, Architectural Planning and Design, pp. 111-112, 2019.7 (in Japanese)

小野田泰明 芳賀瑞穂 佃悠：1990 年代以降の複合型図書館における 運営手法と計画プロセスの特徴 -近年の公共図書館施設整備における 計画プロセスとその特徴 その 2-, 日本建築学会大会学術講演梗概 集, 建築計画, pp. 111-112, 2019.7

4) Kaname SAKAI and Hideaki OSHIMA: PRESENT STATUS OF INSTALLED LIBRARY AND FACILITIES, AND INFLUENCE THAT FACILITIES GIVE TO NUMBER OF VISITORS OF LIBRARY Study on library planning which established in the complex facility, Part1, Journal of Architecture and Planning (Transactions of AIJ), No.752, pp. 1909-1912，2018.10 (in Japanese)

酒井要, 大島秀明：設置された図書館・施設の状況と図書館来館者数 に対する影響＼cjkstart複合施設に設ける図書館整備に関する研究 その 1 , 日本建築学会計画系論文集 第 752 号, pp. 1909-1912，2018. 10

5) Takayuki NAKAI, Takahiro AKINO and Momoko TANIGUCHI: ACTIVITIES AND BEHAVIORS TO SELECT SEATS BASED ON USERS' GENERATION AND AFFILIATION IN LIBRARIES A study on the planning and design of the public library as a "place", Part 1, Journal of Architecture and Planning (Transactions of AIJ), No.741, pp. 2767-2777, 2017. 11 (in Japanese)

中井孝幸，秋野崇大，谷口桃子：図書館における利用者属性からみた 座席の選択行動と過ごし方「場」としての公共図書館の施設計画に関 する研究 その 1, 日本建築学会計画系論文集 第 741 号, pp. 27672777, 2017. 11

6) SATO Taiga, KISHIMOTO Tatsuya: Relations between visitors' movement path, distribution of visitors' activity and space structure in stay-type library, Summaries of Technical Papers of Annual Meeting, Architectural Institute of Japan, Architectural Planning and Design, pp. 105-106, 2016.7 (in Japanese)

佐藤泰雅，岸本達也：滞在型図書館における来館者の移動経路および 活動分布と空間構成の関係, 日本建築学会大会学術講演梗概集, 建築 計画, pp. 105-106, 2016.7

7) MURSE Hisasi, NAKAI Takayuki, TANAKA Ryuitirou: Study on the use incidentally in complex with a library, Summaries of Technical Papers of Annual Meeting, Architectural Institute of Japan, Architectural Planning and Design, pp.51-52, 2016.7 (in Japanese)

村瀬久志，中井孝幸，田中隆一朗：図書館を含む複合施設のついで利 用に関する研究, 日本建築学会大会学術講演梗概集, 建築計画, pp. $51-52,2016.7$

8) Japan Library Association Library Research Business Committee: Nippon no toshyokan Toukei to meibo 2017, Japan Library Association, 2018.2 (in Japanese)
日本図書館協会図書館調査事業委員会：日本の図書館 統計と名簿 2017, 日本図書館協会, 2018.2

9) Suzuki Akira, Minato Chihiro, Tama bijyutsu daigaku toshyokan book project: Tsukuru toshyokan wo tsukuru - Ito toyoo to tama bijyutsu daigaku no jikken, Kajima Institute Publishing Co., Ltd., 2007. 7 (in Japanese)

鈴木明, 港千尋, 多摩美術大学図書館ブックプロジェクト：つくる図 書館をつくる一伊東豊雄と多摩美術大学の実験, 鹿島出版会, 2007.7

10) Tamura Shyunsaku, Ogawa Toshihiko: Koukyou toshyokan no ronten seiri, Keiso Shobo, 2008.2 (in Japanese) 田村俊作，小川俊彦：公共図書館の論点整理，勁草書房，2008.2

11) Uematsu Sadao, Tomie Shinji, Yanase Hiroo, Kawashima Hiroshi, Nakai Takayuki: Yoi toshyokan shisetsu wo tsukuru, Japan Library Association, 2010.3 (in Japanese)

植松貞夫，富江伸治，柳瀬寛夫，川島宏，中井孝幸：よい図書館施設 をつくる，日本図書館協会，2010.3

12) Fukumoto Tooru, Nimura Ken: Basic shishyo kouza Toshyokan no kiso to tenbou 9 Toshyokan shisetsu tokuron, GAKUBUNSHA, 2012. 3 (in Japanese)

福本徹, 二村健：ベーシック司書講座・図書館の基礎と展望 9 図書 館施設特論，学文社，2012.3

13) Miyabe Yoriko: Tosyhokan service gairon, Jusonbo Co., Ltd., 2012.4 (in Japanese)

宮部頼子：図書館サービス概論，樹村房，2012.4

14) Uematsu Sadao: Toshyokan shisetsu ron, Jusonbo Co., Ltd., 2014. 3 (in Japanese) 植松貞夫：図書館施設論，樹村房，2014.3

15) Onoda Yasuaki, Suzuki Yoshihiro, Ito Shyunsuke, Watanabe Akiko, Suzuki Masayuki: Kenchiku no supliment Toraeru kangaeru tsukuru tame no tool, SHOKOKUSHA Publishing Co., Ltd., 2014.4 (in Japanese)

小野田泰明, 鈴木義弘, 伊藤俊介, 渡邊朗子, 鈴木雅之：建築のサプ リメントとらえる・かんがえる・つくるためのツール， 彰国社， 2014.4

16) Horiba Hiroshi, Kudou Kazumi: Toshyokan wo tsukuru, SHOKOKUSHA Publishing Co., Ltd., 2014.11 (in Japanese)

堀場弘, 工藤和美：図書館をつくる，彰国社，2014.11

17) Ikeya Nozomi, Agata Mari, Suga Chie: Toshyokan wa shimin to hon jyouhou wo musubu, Keiso Shobo, 2015. 3 (in Japanese) 池谷のぞみ, 安形麻理, 須賀千絵: 図書館は市民と本・情報をむすぶ, 勁草書房，2015. 3

18) Ministry of Education, Culture, Sports, Science and Technology: Chiiki no joho habu toshite no toshyokan -Kadai kaiketsu gata no toshyokan wo mezashite-, 2005.1. (online), available from 〈http://www. mext. go. jp/a_menu/shougai/tosho/houkoku/05091401/a 11. pdf〉, (accessed 2020.3.10)

文部科学省：地域の情報ハブとしての図書館 -課題解決型の図書館を 目指して-, 2005.1. (オンライン), 入手先〈http://www. mext.go.jp /a_menu/shougai/tosho/houkoku/05091401/all.pdf〉,（参照 2020.3. 10)

19) Ministry of Education, Culture, Sports, Science and Technology: Korekara no toshyokan zou ${ }^{2}$ Chiiki wo sasaeru jyouhou kyoten wo mezashite , 2006.3. (online), available from 〈http://warp. da. ndl. go. jp/info:ndl jp/pid/286184/www. mext. go. jp/b_menu/houdou/1 8/04/06032701/009.pdf>, (accessed 2020.3.10)

文部科学省：これからの図書館像 〜地域を支える情報拠点をめざし て〜 (報告), 2006.3. (オンライン), 入手先〈http://warp. da.ndl. go. jp/info:ndl jp/pid/286184/www. mext.go.jp/b_menu/houdou/18/04 /06032701/009. pdf〉,（参照 2020.3.10）

20) KOMASTU Hisashi, FURUTA Daisuke: Study on Space and Management of Public Library in Consideration of Various Uses - Part1, Summaries of Technical Papers of Annual Meeting, Architectural Institute of Japan, Architectural Planning and Design, pp. 101102, 2017.7 (in Japanese)

小松尚，古田大介：幅広い利用の視点からみた全国公共図書館の館内 空間整備と運営プログラムの現状 幅広い利用に考慮した公共図書館 
の空間と運営に関する研究その 1 , 日本建築学会大会学術講演梗概 集，建築計画，pp. 101-102，2017.7

21) HASIMOTO Ryousuke, YAMAZAKI Toshihiro, SUZUKI Yuiti: Facility Complexed Situation, Subjects of Facility Function and Management for Public Library, Summaries of Technical Papers of Annual Meeting, Architectural Institute of Japan, Architectural Planning and Design, pp. 115-116, 2017.7 (in Japanese)

橋本諒介, 山崎俊裕, 鈴木裕一: 公共図書館の施設複合化状況と施設 面・運営面の課題について, 日本建築学会大会学術講演梗概集, 建築 計画, pp. 115-116, 2017. 7

22) KOJIMA Yuki, KOMATSU Hisashi, FURUTA Daisuke: A study on space of the public library promoting the supports for solving citizen problems, Summaries of Technical Papers of Annual Meeting, Architectural Institute of Japan, Architectural Planning and Design, pp. 99-100, 2017.7 (in Japanese)

小島悠睴，古田大介，小松尚：課題解決支援を推進する公共図書館の 空間整備に関する研究，日本建築学会大会学術講演梗概集，建築計画， pp. 99-100, 2017.7

23) GENG Xu, SAI0 Naoko: Functions and Space Planning of Complex Facilities Containing Public Libraries, Summaries of Technical Papers of Annual Meeting, Architectural Institute of Japan, Architectural Planning and Design, pp. 1035-1038, 2018.7 (in Japanese)

耿旭, 斎尾直子: 公共図書館を含む複合公共施設の機能構成と空間計 画, 日本建築学会大会学術講演梗概集, 建築計画, pp. 1035-1038, 2018. 7

注

注1） 2015 年度の社会教育調査によると、本館・分館を含む公立図書館 3,300 館のうち 1,166 館が単独館、2,164 館が複合館であり、本館・分館と もに複合館の数が単独館を上回っている。

注2）管理者アンケートは、調査対象館 48 館のうち、アンケートへの協力が 得られた 43 館の回答をもとに分析を行った。

注3）調査対象館は、両館ともに指定管理者であるC 社が運営を行っている。 この 2 館以外に加え、C 社が指定管理者として運営する図書館では日 本の図書館において最も標準的に用いられている図書分類法である日 本十進分類法ではなく、本との出会いを重視した独自の分類が採用さ れている。

注4） St 館は、市が進める駅周辺整備事業の一環として図書館を核施設とし 商業機能・飲食店・鉄道駅と複合し、利便性の高い敷地に位置してい る図書館である。また、指定管理者である C 社が図書館運営と書店の 管理を一体で行っており、C 社が指定管理を行う図書館としては調査 時点で 5 館目であった。商業機能の他、施設の 3 階には市が運営する 市民活動支援センターが複合されている。一方 Tg 館は、市の中心市街 地再開発事業の一環として、駅前に建設された複合ビルへ移転した図 書館である。指定管理者 (C 社) が運営する図書館として初めての新築 図書館であり、商業施設や飲食店・ギャラリーなどの機能が複合され ている。

注5）文部科学省によると課題解決型（図書館）とは、地域における情報基 盤の整備を受けて、地域社会における様々な資料や情報を有効活用で きるように供することによって、地域の課題解決やそのための人々の 取組への展開を支援すること等を主な役割とする図書館であることが 示されている。その上で、目指寸心゙き取り組みとして地域課題の解決 支援、個人の自立化支援、地域の教育力向上支援等が挙げられている。

注6）課題解決型（図書館）に対し、近年、従来の図書館サービスに加えて、 館内での来館者の滞在を意識した空間づくりやサービスの提供を行う 図書館も増加している。これらの図書館は一般に滞在型（図書館）と 呼ばれることが多いが明確な定義づけはなされていない。そこで本研 究では滞在型 (図書館) を、誰もが気軽に訪れ、館内で様々なサービ スを楽しみながら長時間快適に過ごすことのできる図書館と定義した。

注7） $11: 30 \sim 13: 00 、 16: 30 \sim 18: 00$ の時間帯は多くの施設利用者の昼食、夕 食時間带と重なっていることもあり、飲食等を目的とした離着席や部 屋の出入りが他の時間帯に比べて極端に多いことが予備調査より明ら かとなった。これらの利用行動については本節で分析対象とする図書 空間を中心とした座席利用とは、その動機や頻度等において著しく異 なる動態を示すため調査からは除外した。
注8）調査当日、St 館の 2 階テラス部分においてマルシェイベントが開催さ れており、その参加者が多数来館していた。この状況は特殊な状況下 ともとらえられるが、当該図書館では年間を通して様々なイベントが 企画されており、何らかのイベントが館内で開催されている。そのた め、イベント開催時の状況が当該図書館の休日の一般的な状態と判断 して分析を行った。

注9）調査当日、併設するカフェエリアでライブイベントが開催されており、 その参加者が多数来館していた。上記と同様の理由からこれも当該図 書館の休日の一般的な状態と判断して分析を行った。

注10）来館者へのアンケートは、来館者の退館時に調査員による声掛けによ る現地回答の方式で行った。調査場所については、St 館ではバスター ミナルと接続する 1 階北側メインエントランスと駅に接続する 2 階の テラス部分に面するサブエントランス、Tg 館では駅に面した 1 階東側 メインエントランスと 1 階北側サブエントランスに調査員を複数配置 し、施設外部と接続する場所にて実施することで、来館者の属性によ るサンプルに偏りが生じることなく全体の傾向をとらえることができ るよう配慮した。

注11） Fig. 6〜Fig. 8 の回答者数は来館者へのアンケート調査の全調査回答 者数（St 館 : 平日 116 人、休日 115 人、 $\mathrm{Tg}$ 館 : 平日 111 人、休日 111 人）のうち、来館目的の有無と利用施設について回答が得られた有効 回答数 (St 館 : 平日 112 人、休日 112 人、 $\mathrm{Tg}$ 館 : 平日 104 人、休日 108 人) をもとにした。なお、Fig. 5 は全調査回答者数をもとにした。

注12）Fig. 6、Fig.7 の破線表現の $\square$ 「当初は目的施設としていたが、実際 には利用しなかった施設」を表すため、目的内利用のパターン数には 含めない。 


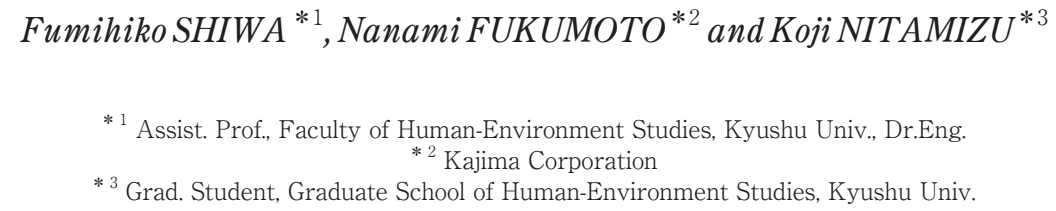

This research clarifies the following issues to obtain useful knowledge for future public library planning by capturing the behavior of the complex public library in recent years based on the user's purpose of visit.

First, the functional structure and management policy of the complex public library in recent years were examined, and then, elucidated the following points. 1) With respect to the functional composition of complex facilities, most such facilities combine social education facilities, mainly for culture and learning, and commercial and industrial facilities, mainly restaurants, as well as integrate multiple functions in one building, compared with other facilities. 2) In the management policy, problem`solving orientation aiming to enhance reference functions as a regional information base and the stay orientation that aims to provide a full range of services, cozy space, and place for interaction are emphasized. 3) The policy as a regional information base in the problem-solving orientation is emphasized in the directly managed library; on the other hand, its stay orientation—mainly providing a cozy space and full range of services—is emphasized in the designated manager-type library.

Second, the connection between users' purpose of visit and the space used at St and Tg libraries were clarified. 4) At both the libraries, reading in the reading room, studying in the study room, and taking a break in the café were observed to be common on weekdays and holidays. In addition, compared with the reading room, the study room and café had different peak usage times on weekdays and holidays_-because of this difference, the inflow of users from the adjacent station could be seen at St Library, and the outflow of users from the study room to other spaces at Tg Library. 5) While users had a certain number of limited purposes of visit on holidays at both St and Tg libraries, there are many resting purpose that does not directly aim at the original function of the library in St library and the purpose of the solution utilizing the original function of the library in Tg library. 6) Regarding the relationship with usage, the ratio of purposespecific use is high in both St and Tg libraries, but the ratio is reversed for use on weekdays and holidays. Especially in the purpose-specific use, by the way use is based on the library use, and then the use is expanded in the St library. On the other hand, although the library is mainly used, many other facilities are single or multiple use and various other facilities are the starting point for by the way use in the Tg library. 7) Furthermore, stop by use was higher at St Library, which is directly connected to the station, as opposed to Tg Library. Approximately $60 \%$ of the stop by users used multiple spaces on weekdays and holidays—-the bookstore and café near the reading room on the floor where the main entrance is located emerged as the starting points. 8) Especially on holidays, when there are fewer time constraints for stop by users, the space used extended to non-adjacent spaces. In addition, this tendency was even more pronounced at Tg Library where the visual connection of space is emphasized. 